\title{
Extraction of flavonoids from Chrysanthemum morifolium and antitumor activity in vitro
}

\author{
YING-HUI LIU, XIN MOU, DI-YI ZHOU, DAN-YANG ZHOU and CHENG-MIN SHOU \\ Department of Endocrinology, Integrated Chinese and Western Medicine Hospital of Zhejiang Province, \\ Hangzhou, Zhejiang 310003, P.R. China
}

Received August 5, 2016; Accepted May 11, 2017

DOI: $10.3892 /$ etm.2017.5574

\begin{abstract}
The aim of the present study was to optimize flavonoid extraction from Chrysanthemum morifolium and to study the antitumor effects of flavonoids on human gastric cancer MKN45 cells in vitro. A single factor experiment was designed and the extraction process was optimized using an orthogonal test. MKN45 cells were treated with different concentrations of flavonoid from Chrysanthemum morifolium for 24 and $48 \mathrm{~h}$ and the inhibitory effect on the MKN45 cells was evaluated using an MTT assay. Following staining with Annexin V-fluorescein isothiocyanate/propidium iodide, flow cytometry was performed. The optimized flavonoid extraction conditions were as follows: Duration of ultrasonic treatment: $35 \mathrm{~min}$; ethanol concentration: $75 \%$; extraction temperature: $80^{\circ} \mathrm{Cand}$ liquid-to-solid ratio 25: 1 . Under the above conditions, the extraction rate of flavonoids was $5.24 \%$. When compared with a blank control group, flavonoids extracted from Chrysanthemum morifolium inhibited the proliferation of MKN45 cells in a dose- and time-dependent manner. Furthermore, in cell groups treated with low, moderate and high concentrations of flavonoid, it was observed that the proportion of apoptotic cells increased in a dose-dependent manner. The extraction process optimized by the orthogonal test achieved a high yield and satisfactory extraction efficiency. Additionally, the experiment demonstrated that flavonoids from Chrysanthemum morifolium inhibited the growth of MKN45 cells and induced their apoptosis. Thus, flavonoids from Chrysanthemum morifolium exerted antitumor effects on MKN45 cells, which may be exploited as a potential antitumor therapeutic for gastric cancer.
\end{abstract}

Correspondence to: Dr Xin Mou, Department of Endocrinology, Integrated Chinese and Western Medicine Hospital of Zhejiang Province, 208 Ring East Road, Hangzhou, Zhejiang 310003, P.R. China

E-mail: mouxin_mx@163.com

Key words: Chrysanthemum morifolium, flavonoids, orthogonal test, flow cytometry, cell apoptosis

\section{Introduction}

Chrysanthemum morifolium is a species of perennial plant from the Asteraceae family. Also known as mums, Chrysanthemum morifolium is among the four most famous chrysanthemum species in China. According to traditional Chinese medicine principles, Chrysanthemum morifolium has been indicated to be 'cool' in nature and 'acrid' in taste, and exhibits affinity for the lung and liver systems (1). Furthermore, according to traditional Chinese medicine, chrysanthemum is able to improve eyesight and prevent fatigue (2). Chrysanthemum may be used to treat wind-heat type common cold, headache and dizziness, red and painful eyes and toxin-induced swelling. The main ingredients of Chrysanthemum morifolium are volatile oils (3), flavonoids (4), chlorogenic acid (5), polysaccharides (6), phenols (7) and trace elements (8). Flavonoid compounds, triterpenoids and volatile oils are the main active components (9). Flavonoids from Chrysanthemum morifolium may significantly improve the activity of antioxidases in the tissues of rats with lead poisoning, relieve lipid peroxidation and antagonize oxidative injury of the brain, liver and kidney (10). In addition, flavonoids from Chrysanthemum morifolium downregulated high glucose-induced B-cell lymphoma 2 (Bcl-2)-associated $\mathrm{X}$ protein expression and upregulated $\mathrm{Bcl}-2$ in vascular endothelial cells (VECs), while inducing the apoptosis of VECs (11). These benefits may be exploited for the treatment of diabetic angiopathy. Thus, Chrysanthemum morifolium may be used as a clinical medicineand for health purposes due to its medicinal value.

Extraction and separation of the active components from medicinal herbs are key to understanding the composition and biological activities of the herbs $(12,13)$. Even for the same medicinal herb, the yield of active components may differ under different extraction conditions. The orthogonal test design is an effective tool for determining the optimal combination of extraction conditions and their optimum levels (14). To understand the effect of 4 independent factors each with 3 factor level values $\left(3^{4}\right), 81$ runs are typically required, excluding the repeats for each combination (15). With an $\mathrm{L}_{9}\left(3^{4}\right)$ orthogonal array, 9 runs are required (16). The present study used an orthogonal test design to evaluate flavonoid extraction from Chrysanthemum morifolium via ultrasonic treatment. 
The optimal extraction conditions were determined to achieve the optimal yield and extraction efficiency.

In the last 10 years, the incidence of cancer has increased due to the accelerating pace of urban life, environmental pollution and food safety issues, and greater proportions of young adults are now being diagnosed with cancer (17). Chrysanthemum morifolium is considered to have a number of pharmacological activities, including the ability to remove free radicals (18) and anti-inflammatory (19), immunoregulatory (20) and antitumor effects (21). For instance, flavonoids extracted from Chrysanthemum morifolium exhibited significant cytotoxicity in human colorectal cancer cells (22). The present study evaluated the flavonoids extracted from Chrysanthemum morifolium, and an antitumor effect against human gastric cancer MKN45 cells was determined by an MTT assay. In addition, the apoptosis of MKN45 cells was evaluated by flow cytometry. The purpose of this was to confirm the clinical effects of Chrysanthemum morifolium on cancer cells.

\section{Materials and methods}

Materials. Chrysanthemum morifolium was purchased from Tongxiang Datong Industrial \&Trading Co., Ltd. (Tongxiang, China); rutin reference standard (batch number 42045) was purchased from the National Institutes for Food and Drug Control (Beijing, China); human gastric cancer MKN45 cells were provided by the Microbiology and Immunology Teaching and Research Section at the School of Basic Medical Sciences of Zhejiang Chinese Medical University (Hangzhou, China).

Reagents. Reagents purchased for the present study were $0.25 \%$ trypsin- $0.02 \%$ EDTA (Jinuo Biomedical Technology Co., Ltd., Hangzhou, China), fetal bovine serum (FBS), Roswell Park Memorial Institute (RPMI) 1640 medium (both from Hangzhou Sijiqing Biological Engineering Co., Ltd., Hangzhou, China), an MTT assay kit (Amresco LLC, Solon, OH, USA), an Annexin V-fluorescein isothiocyanate/propidium iodide (FITC/PI)apoptosis detection kit (Nanjing KeyGen Biotech Co., Ltd., Nanjing, China). All other reagents were manufactured domestically and analytically pure.

Equipment. A TU-1950 UV-Vis spectrophotometer (Beijing Purkinje General Instrument Co., Ltd., Beijing, China), M5800H-C ultrasonic cleaner (Branson Ultrasonics Co., Ltd., Shanghai, China), Varioskan Flash microplate reader (Thermo Fisher Scientific, Inc., Waltham, MA, USA), IX70 inverted phase-contrast microscope (Olympus Corporation, Tokyo, Japan), FACSCalibur flow cytometer (BD Biosciences, Franklin Lakes, NJ, USA) were used.

Grouping. Four cell groups were used: Group A (blank control), which was treated with RPMI-1640 medium alone; group B (low-dose treatment), treated with RPMI-1640 medium containing $5 \mathrm{mg} / \mathrm{mlflavonoids}$; group C (moderate-dose treatment), treated with RPMI-1640 medium containing $10 \mathrm{mg} / \mathrm{ml}$ flavonoids; and group D (high-dose treatment), treated with RPMI-1640 medium containing $20 \mathrm{mg} / \mathrm{ml}$ flavonoids.

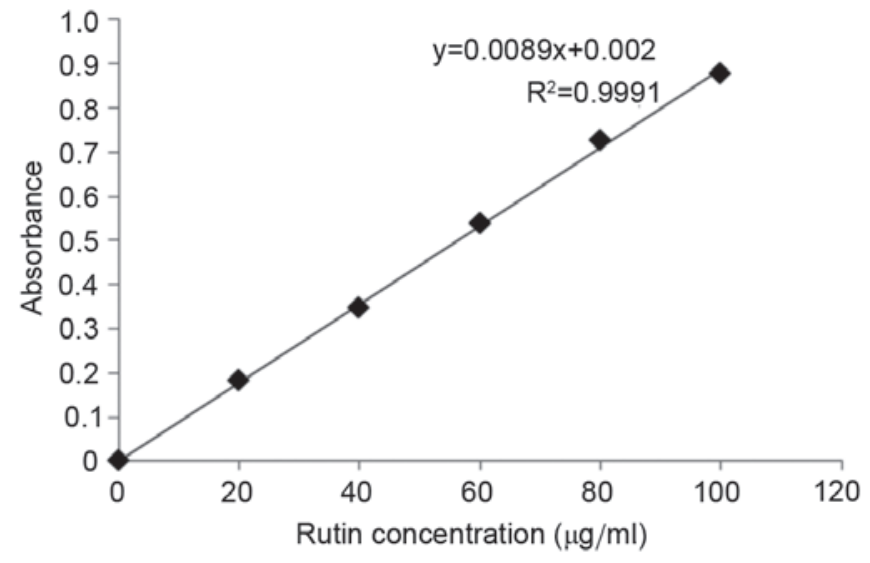

Figure 1. Standard curve regression equation.

\section{Optimization of the extraction process}

Extraction procedures. Chrysanthemum morifolium weighing $2.0 \mathrm{~g}$ was cut into pieces and placed into a $100-\mathrm{ml}$ round-bottom flask. Ultrasonic extraction was performed at different temperatures with the addition of ethanol using a M5800H-C ultrasonic cleaner (Branson Ultrasonics Co., Ltd., Shanghai, China) and at a frequency of $80 \mathrm{kHz}$. After extraction, a 100 mesh screen (pore size, $0.150 \mathrm{~mm}$ ) was used to obtain the filtrate, which was centrifuged at $12,000 \mathrm{~g}$ at $4^{\circ} \mathrm{C}$ for $30 \mathrm{~min}$ to remove the impurities. Ethanol was removed by rotary evaporation. The supernatant was then collected and condensed at a reduced pressure $\left(-0.08-0.1 \mathrm{MPa}, 50-65^{\circ} \mathrm{C}\right.$ for $1 \mathrm{~h})$ to obtain the crude extract of flavonoids.

Plotting of standard curve. A rutin reference standard of $0.5 \mathrm{mg}$ was used (rutin was dried at $120^{\circ} \mathrm{C}$ to $5.0 \mathrm{mg}$ ) and placed into a $25.0 \mathrm{ml}$ volumetric flask. Ethanol (60\%) was added to a constant volume $(25.0 \mathrm{ml})$ to obtain a $0.2 \mathrm{mg} / \mathrm{ml}$ standard solution of rutin. Volumes of the standard rutin solution $(0.0,1.0,2.0,3.0,4.0$ and $5.0 \mathrm{ml})$ were placed into $10.0 \mathrm{ml}$ volumetric flasks. A total of $0.3 \mathrm{ml}$ of $5 \%$ sodium nitrite (Sinopharm Chemical Reagent Co., Ltd., Shanghai, China) solution was then added, mixed and allowed to stand at room temperature for $6 \mathrm{~min}$, after which $0.3 \mathrm{ml}$ of $10 \%$ aluminum nitrite (Sinopharm Chemical Reagent Co., Ltd.) solution was added, mixed and allowed to stand at room temperature for $6 \mathrm{~min}$. Following the addition of $4.0 \mathrm{ml}$ sodium hydroxide $(1.0 \mathrm{~mol} / \mathrm{l}), 60 \%$ ethanol was added to a constant volume $(10 \mathrm{ml})$. After standing at room temperature for $10 \mathrm{~min}$, absorbance was measured using a TU-1950 $\mathrm{UV}-\mathrm{V}$ is spectrophotometer at $510 \mathrm{~nm}$ and a standard curve was plotted with concentration on the $\mathrm{x}$ axis and absorbance on the $y$ axis (Fig. 1). A regression equation was fitted as follows: $\mathrm{y}=0.0089 x+0.002$ and $\mathrm{R}^{2}=0.9991$.

Determination of flavonoid content. Crude extract of flavonoids $(1 \mathrm{ml})$ was placed into a tube and subjected to the same treatment protocol of the rutin reference standard. The absorbance was measured and flavonoid concentration was calculated from the standard curve. The extraction efficiency (\%) was also calculated as follows: extraction efficiency $(\%)=$ extracted flavonoid content/total mass of Chrysanthemum morifolium powder x 100 (16). 
Table I. $\mathrm{L}_{9}\left(3^{4}\right)$ orthogonal array.

\begin{tabular}{lcccc}
\hline \multicolumn{5}{c}{ Factor } \\
\cline { 2 - 5 } Level & $\begin{array}{c}\text { Duration, } \\
\text { min }\end{array}$ & $\begin{array}{c}\text { Ethanol } \\
\text { concentration, } \%\end{array}$ & $\begin{array}{c}\text { Temperature, Liquid-to- } \\
{ }^{\circ} \mathrm{C}\end{array}$ & $\begin{array}{c}\text { Lolid ratio } \\
\text { solio }\end{array}$ \\
\hline 1 & 30 & 65 & 70 & $20: 1$ \\
2 & 35 & 70 & 75 & $25: 1$ \\
3 & 40 & 75 & 80 & $30: 1$ \\
\hline
\end{tabular}

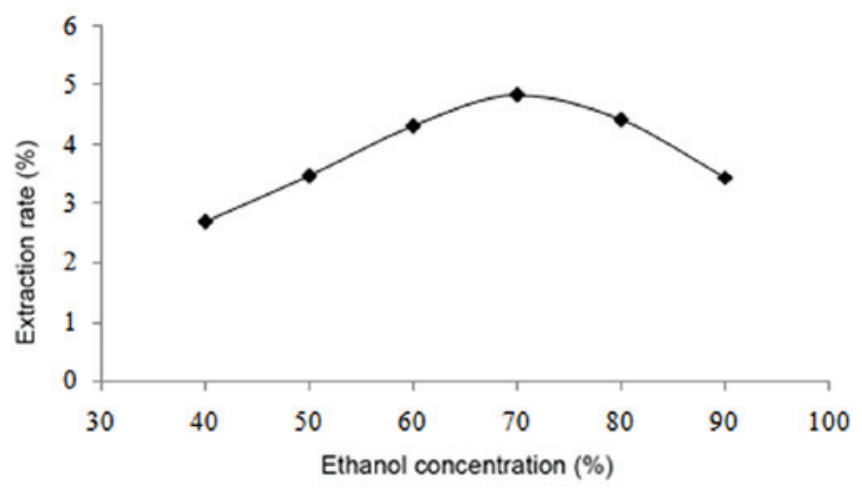

Figure 2. Effect of ethanol concentration of flavonoid extraction.

Single factor experiment. The initial extraction parameters were as follows: $60 \%$ ethanol, 10:1 liquid-to-solid ratio, $80^{\circ} \mathrm{C}$ extraction temperature and $30 \mathrm{~min}$ duration of ultrasonic treatment. The above conditions were optimized in order to maximize the yield. The following 6 levels were assessed for each factor: 40, 50, 60, 70, 80 and 90\% ethanol concentration; 10:1, 15:1, 20:1, 25:1, 30:1 and 35:1 liquid-to-solid ratio; $50,60,70,80,90$ and $100^{\circ} \mathrm{C}$ temperature; and 10, 20, 30, 40, 50 and 60 min duration. The effect of each factor on the yield was assessed to determine the optimum level for each factor.

Orthogonal test design. Based on the above single factor experiment, 4 factors (duration, ethanol concentration, temperature and liquid-to-solid ratio) were selected to form an $\mathrm{L}_{9}\left(3^{4}\right)$ orthogonal array (Table I).

Cell Morphology changes. Human gastric cancer MKN45 cells were seeded at a density of $1 \times 10^{3}$ cells/well into 96 -well plates and allowed to adhere for $24 \mathrm{~h}$ at $37^{\circ} \mathrm{C}$ in an atmosphere containing $5 \% \mathrm{CO}_{2}$. Flavonoid solutions, at concentrations of $0,5,10$ and $20 \mathrm{mg} / \mathrm{ml}$ were added to the wells, and the cells were cultured for $24 \mathrm{~h}$ at $37^{\circ} \mathrm{C}$. Morphological changes were observed using IX70 inverted phase-contrast microscope (magnification, $\mathrm{x} 200$ ) in a blinded manner.

Detection of antitumor effects of flavonoids. Human gastric cancer MKN45 cells were placed in RPMI-1640 medium supplemented with $10 \% \mathrm{FBS}$ and cultured at $37^{\circ} \mathrm{C}$ in a $5 \%$ $\mathrm{CO}_{2}$ incubator. The culture medium was discarded when MKN45 cells reached $80 \%$ confluence, and the cells were washed once/twice with PBS and digested with $2.0 \mathrm{ml} 0.25 \%$ trypsin- $0.02 \%$ EDTA to prepare a cell suspension. With cell density adjusted to $5-6 \times 10^{4}$ cells $/ \mathrm{ml}$, the cells were inoculated into 96 -well plates (100 $\mu \mathrm{l} /$ well), and the culture medium was replaced by fresh medium after $24 \mathrm{~h} 37^{\circ} \mathrm{C}$. Subsequently, $0,5,10$ and $20 \mathrm{mg} / \mathrm{ml}$ of crude flavonoids were added to the blank control group (group A) and the three treatment groups (groups B, C and D). Each treatment was replicated three times at $37^{\circ} \mathrm{C}$. MTT solution $(5 \mathrm{mg} / \mathrm{ml})$ was added 24 or $48 \mathrm{~h}$ later $\left(\right.$ at $37^{\circ} \mathrm{C}$ ) and the culture medium was discarded $4 \mathrm{~h}$ later. Dimethyl sulfoxide was then added to dissolve the precipitate and the cells were oscillated for $10 \mathrm{~min}$. The absorbance was measured at $570 \mathrm{~nm}$ using Varioskan Flash microplate reader, and the cell inhibition rate was calculated as follows: Cell inhibition rate $(\%)=\left(1-\mathrm{OD}_{570 \mathrm{~nm}}\right.$ value of the treatment group/OD ${ }_{570 \mathrm{~nm}}$ value of the blank control group) x 100 (23).

Flow cytometry of cell apoptosis. Log-phase MKN45 cells were harvested with cell density adjusted to $1 \times 10^{5}$ cells $/ \mathrm{ml}$. The cells were inoculated into 6 -well plates at $1 \mathrm{ml} /$ well containing RPMI-1640 medium supplemented with 10\% FBS. The cells were treated with flavonoids of different concentrations $(0.0,5.0,10.0$ and $20.0 \mathrm{mg} / \mathrm{ml})$ after cell culture for $24 \mathrm{~h}$ at $37^{\circ} \mathrm{C}$. The cells were then digested with EDTA-free $0.25 \%$ trypsin (Jinuo Biomedical Technology Co., Ltd., Hangzhou, China) and centrifuged at $100 \mathrm{x}$ g for $5 \mathrm{~min}$ at $25^{\circ} \mathrm{C}$. The supernatant was discarded and the cells were washed twice with pre-cooled PBS. A total of $500 \mu \mathrm{l}$ binding buffer (eBioscience; Thermo Fisher Scientific, Inc.) was added to $1 \times 10^{5}$ cells to resuspend them, followed by staining with $5.0 \mu \mathrm{l}$ Annexin V-FITC and 5.0 $\mu \mathrm{l} \mathrm{PI}$ at room temperature for $15 \mathrm{~min}$ in the dark. A total of $400 \mu \mathrm{l}$ binding buffer was then added to cells. As a negative control, a group of cells was not stained with Annexin V-FITC or PI. Cell apoptosis was detected using a FACSCalibur flow cytometer (BD Biosciences, Franklin Lakes, NJ, USA) within $1 \mathrm{~h}$.

Apoptosis assay using Annexin V-FITC/PI. Normal, necrotic and apoptotic cells were discriminated by staining with Annexin V-FITC/PI. A dual parameter dot plot was prepared based on the intensity of fluorescence emitted by FITC and PI. Cells were divided into 4 zones: B1, with mechanically damaged cells (Annexin V-FITC-/PI+); B2, with late apoptotic or necrotic cells (Annexin V-FITC+/PI+); B3, with living cells (Annexin V-FITC-/PI-); and B4, with early apoptotic cells (Annexin V-FITC+/PI-). The proportions of the different cells were compared between the treatment groups.

Statistical analysis. Statistical analyses were performed using SPSS 19.0 software (IBM Corp., Armonk, NY, USA). The data were presented as the mean \pm standard deviation of three independent experiments. Statistical differences between the means were analyzed using one-way analysis of variance with Turkey post hoc test. $\mathrm{P}<0.05$ was considered to indicate statistical significance.

\section{Results}

Single factor experiment. The results demonstrated that the yield of flavonoids increased up to an ethanol concentration of 


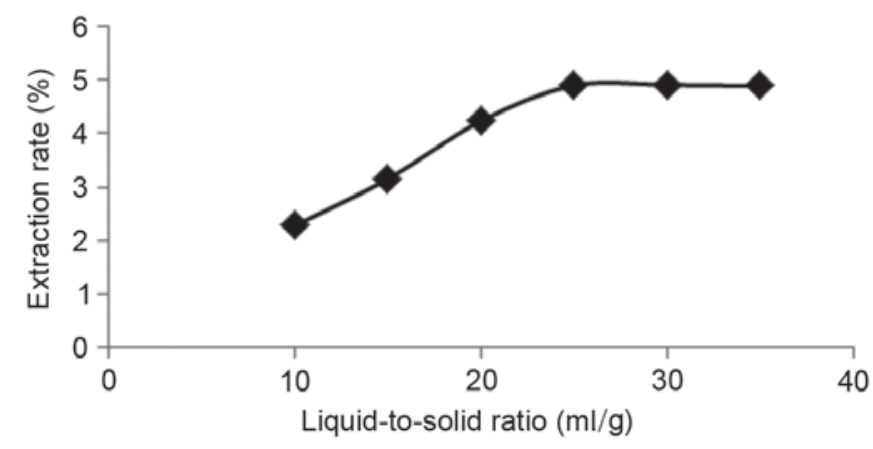

Figure 3. Effect of the liquid-to-solid ratio on flavonoid extraction.

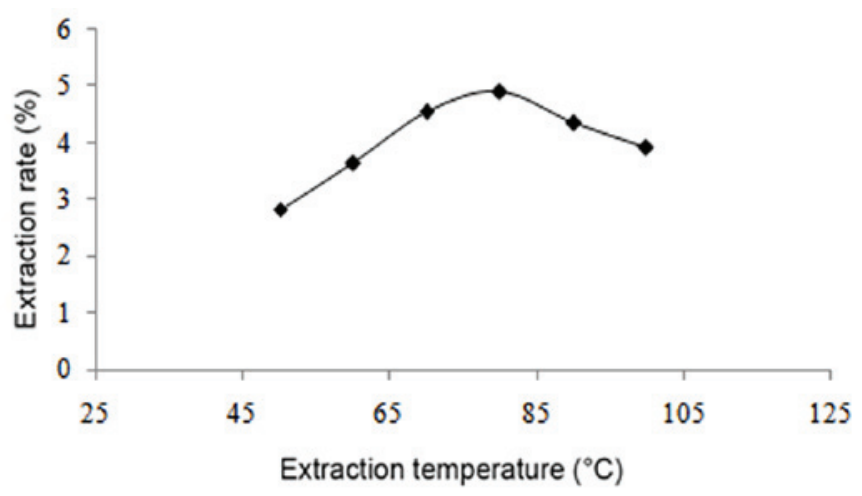

Figure 4. Effect of temperature on flavonoid extraction.



Figure 5. Effect of duration of ultrasonic treatment on flavonoid extraction.

$70 \%$, after which the yield of flavonoids decreased (Fig. 2). As the liquid-to-solid ratio increased from 10:1 to 25:1, the yield of flavonoids also increased; however, when the liquid-to-solid ratio was above $25: 1$, the yield remained mostly unchanged (Fig. 3). With regard to the influence of temperature, the yield increased with a temperature increase from 50 to $80^{\circ} \mathrm{C}$, though began to decline when the temperature was $>80^{\circ} \mathrm{C}$ (Fig. 4). Furthermore, the yield of flavonoids increased with a longer duration of ultrasonic treatment, reaching a maximum at $40 \mathrm{~min}$, after which the yield slightly declined (Fig. 5). These results indicated that the optimal extraction conditions were $70 \%$ ethanol concentration, $25: 1$ liquid-to-solid ratio, $80^{\circ} \mathrm{C}$ temperature and $40 \mathrm{~min}$ duration of ultrasonic treatment.
Table II. Orthogonal test design.

\begin{tabular}{lccccc}
\hline & \multicolumn{5}{c}{ Factor } \\
\cline { 2 - 4 } Run no. & A & B & C & D & Yield, \% \\
\hline 1 & 1 & 1 & 1 & 1 & 3.46 \\
2 & 1 & 2 & 2 & 2 & 3.96 \\
3 & 1 & 3 & 3 & 3 & 4.48 \\
4 & 2 & 1 & 2 & 3 & 4.81 \\
5 & 2 & 2 & 3 & 1 & 5.03 \\
6 & 2 & 3 & 1 & 2 & 4.82 \\
7 & 3 & 1 & 3 & 2 & 4.32 \\
8 & 3 & 2 & 1 & 3 & 3.64 \\
9 & 3 & 3 & 2 & 1 & 3.86 \\
$\mathrm{~K}$ & & & & & \\
1 & 3.97 & 4.20 & 3.97 & 4.12 & \\
2 & 4.89 & 4.21 & 4.21 & 4.37 & \\
3 & 3.94 & 4.39 & 4.61 & 4.31 & \\
$\mathrm{R}$ & 0.95 & 0.19 & 0.64 & 0.25 & \\
\hline
\end{tabular}

Data are presented as the mean. 1,2 and 3 represent the factor levels 1,2 and 3 , respectively (30,35 and 40 min duration; 65,70 and $75 \%$ ethanol concentration, 70,75 and $80^{\circ} \mathrm{C}$ temperature and $20: 1,25: 1$ and 30:1 liquid-to-solid ratio'. A, duration of ultrasonic treatment; B, ethanol concentration; $\mathrm{C}$, temperature; $\mathrm{D}$, liquid-to-solid ratio; $\mathrm{K}$, the mean of the corresponding levels of flavonoids yield at each factor; $\mathrm{R}$, the difference between the maximum and minimum values of $\mathrm{K}$ under each factor.

Results of orthogonal test. The duration of ultrasonic treatment had the greatest impact on flavonoids yield $(\mathrm{R}=0.95)$, followed by temperature $(\mathrm{R}=0.64)$, liquid-to-solid ratio $(\mathrm{R}=0.25)$ and ethanol concentration $(\mathrm{R}=0.19)$ (Table II). The optimal combination of flavonoid extraction conditions was determined to be 35 min duration of ultrasonic treatment, $75 \%$ ethanol concentration, $80^{\circ} \mathrm{C}$ temperature and 25:1 liquid-to-solid ratio $\left(\mathrm{A}_{2} \mathrm{~B}_{3} \mathrm{C}_{3} \mathrm{D}_{2}\right.$, with the letter denoting the factor and number denoting the level). The optimal combination was not included in the orthogonal table, however, the results of a different analysis (the 'extreme difference analysis') indicated what the optimum conditions were, and subsequent experiments demonstrated that the extraction yield was highest under those conditions. In the sixth orthogonal experiment, only the extraction temperature did not meet the optimum combination, but this experiment produced the higher extraction yield (4.82\%), which suggested these experimental conditions (Duration of ultrasonic treatment: $35 \mathrm{~min}$; ethanol concentration: $75 \%$; extraction temperature: $80^{\circ} \mathrm{C}$ and liquid-to-solid ratio $25: 1$, $\mathrm{A}_{2} \mathrm{~B}_{3} \mathrm{C}_{3} \mathrm{D}_{2}$ ) may be optimal. In order to redefine the optimum conditions, the extraction experiments were performed under this condition $\left(\mathrm{A}_{2} \mathrm{~B}_{3} \mathrm{C}_{3} \mathrm{D}_{2}\right)$, and the extraction yield of flavonoids reached $5.24 \%$. So this deduced condition was rationally confirmed to be the best combination of different parameters. However, one-way analysis of variance indicated that only the duration of ultrasonic treatment had a significant impact on flavonoid extraction yield $(\mathrm{P}<0.05$; Table III). 
Table III. One-way analysis of variance of the orthogonal test data.

\begin{tabular}{lcccr}
\hline Factor & Sum of squares & Degree of freedom & Mean square & F-value \\
\hline A & 1.743 & 2 & 0.872 & 16.922 \\
B & 0.067 & 2 & 0.034 & 0.650 \\
C & 0.621 & 2 & 0.311 & 6.029 \\
D & 0.103 & 2 & 0.052 & 1.000 \\
Error & 0.100 & 2 & 0.050 & - \\
\hline
\end{tabular}

$\mathrm{F}_{0.01}(2,2)=99.00, \mathrm{~F}_{0.05}(2,2)=19.00 ; \mathrm{a}: \mathrm{P}<0.05\left[\mathrm{~F}>\mathrm{F}_{0.05}(2,2)\right] . \mathrm{F}_{0.01}(2,2)=99.00, \mathrm{~F}_{0.05}(2,2)=19.00$ are the value obtained by referring to the critical value table of F. P-value of less than 0.05 by the test was considered a statistically significant difference. A, duration of ultrasonic treatment; $\mathrm{B}$, ethanol concentration; $\mathrm{C}$, temperature and $\mathrm{D}$, liquid-to-solid ratio.
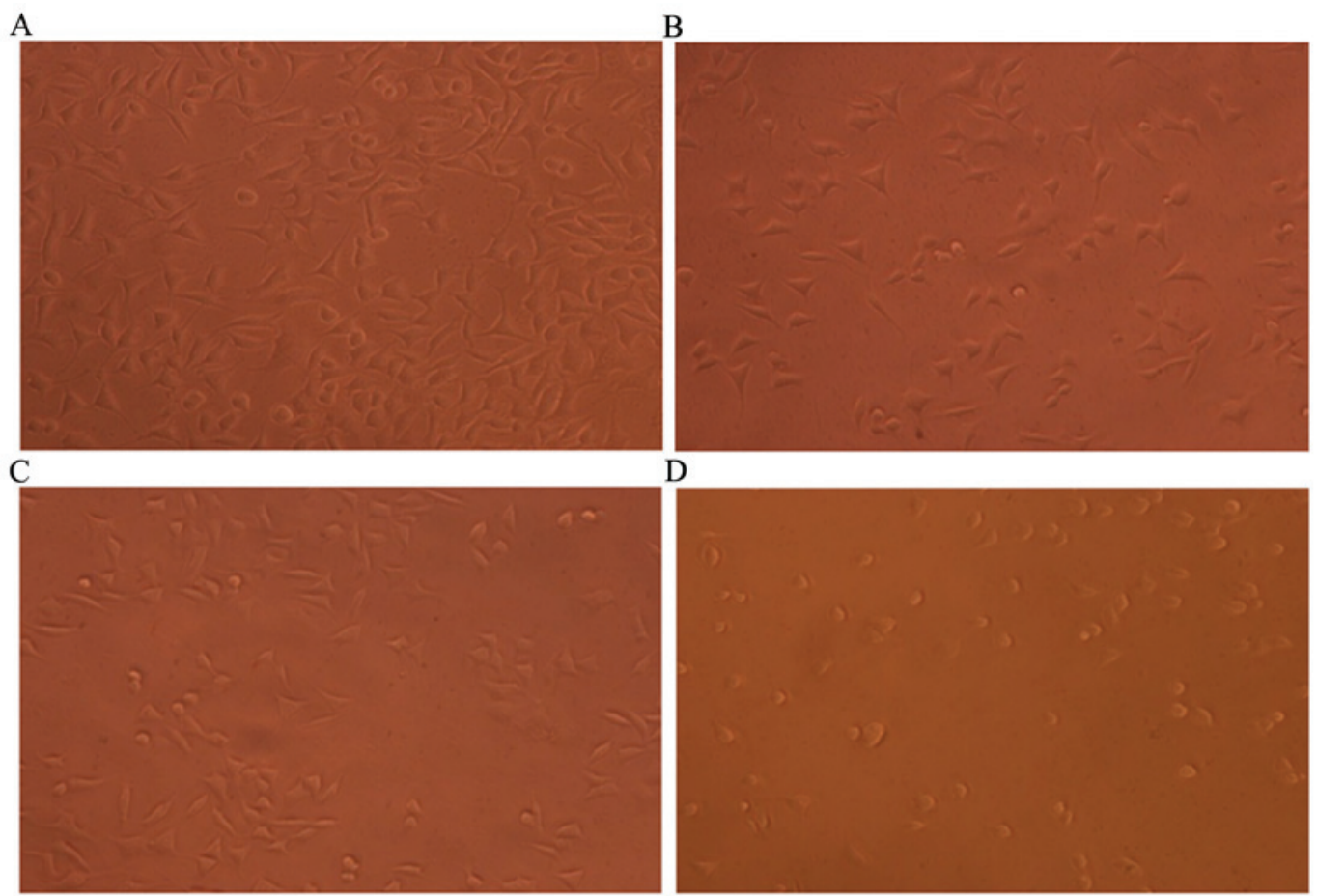

Figure 6. Cell growth in the different treatment groups. (A) Blank; (B) low-dose (5 mg/ml); (C) moderate-dose (10 mg/ml); and (D) high-dose (20 mg/ml) groups. Morphology of MKN45 cells treated with flavonoid $(0.0,5.0,10.0$ and $20.0 \mathrm{mg} / \mathrm{ml})$ for $24 \mathrm{~h}$ was observed using a IX70 inverted phase-contrast microscope (magnification, $\mathrm{x} 200$ ).

Effects of flavonoid concentration on cell morphology. Morphological observation of MKN45 cells treated with flavonoid $(0.0,5.0,10.0$ and $20.0 \mathrm{mg} / \mathrm{ml})$ for $24 \mathrm{~h}$ was performed using IX70 inverted phase-contrast microscopy. A total of $24 \mathrm{~h}$ after cells treated with flavonoid, the cells in different concentrations indicated different degrees of adherence. In the blank control group, cells grew normally, exhibiting tight adherence, a regular pattern and distinct cell morphology, and a large number of cells was observed (Fig. 6A). In the low-dose group, a small number of cells lost the original morphology and exhibited a widened intercellular space and irregular arrangement, and a small number of apoptotic cells were present (24) (Fig. 6B). Morphological characteristics of apoptosis were observed in cells: Cell shrinkage, cell size reduction, and membrane blebbing. Compared with the low-dose group, an increased number of cells in the moderate-dose group lost the original morphology, and more suspended cells and less adherent cells were observed. The number of apoptotic cells was also increased (Fig. 6C). In the high-dose group, the majority of cells lost the original morphology. The cells were round and shrunken, and the large majority were apoptotic (Fig. 6D). These results suggested that flavonoids extracted from Chrysanthemum morifolium exerted antitumor effects in a dose-dependent manner.

Proliferation of MKN45 cells following treatment with different concentrations of flavonoids. Following drug treatment for 24 and $48 \mathrm{~h}$, cell growth was significantly inhibited in groups $\mathrm{B}(\mathrm{P}<0.05), \mathrm{C}$ and $\mathrm{D}$ (both $\mathrm{P}<0.01)$ when compared with the blank control group (group A). Inhibition of cell growth was also significantly greater in groups $\mathrm{C}$ and $\mathrm{D}$ when 
Table IV. Effect of flavonoids on the proliferation activity of MKN45 cells.

\begin{tabular}{llcccc}
\hline & \multicolumn{2}{c}{$24 \mathrm{~h}$} & \multicolumn{2}{c}{$48 \mathrm{~h}$} \\
\cline { 2 - 4 } Group & Absorbance & Inhibition rate, $\%$ & Absorbance & Inhibition rate, \% \\
\hline A & $0.696 \pm 0.021$ & - & $0.686 \pm 0.012$ & - \\
B & $0.656 \pm 0.046^{\mathrm{a}}$ & 5.7 & $0.650 \pm 0.007^{\mathrm{a}}$ & 6.6 \\
$\mathrm{C}$ & $0.548 \pm 0.018^{\mathrm{b}, \mathrm{c}}$ & 21.3 & $0.506 \pm 0.046^{\mathrm{b}, \mathrm{c}}$ & 27.3 \\
$\mathrm{D}$ & $0.343 \pm 0.020^{\mathrm{b}, \mathrm{c}}$ & 50.7 & $0.249 \pm 0.017^{\mathrm{b}, \mathrm{c}}$ & 64.2 \\
\hline
\end{tabular}

Data are presented as the mean \pm standard deviation, $n=3$. ${ }^{\mathrm{a}} \mathrm{P}<0.05$ and ${ }^{\mathrm{b}} \mathrm{P}<0.01$ vs. group $\mathrm{A} ;{ }^{\mathrm{c}} \mathrm{P}<0.01$ vs. group $\mathrm{B}$. A, blank control; $\mathrm{B}$, low-dose; C, moderate-dose; D, high-dose.

A

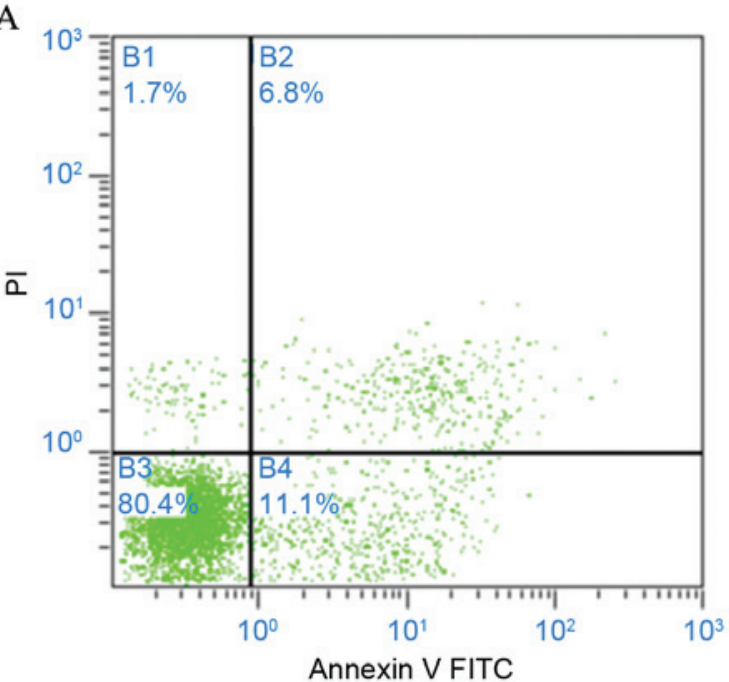

$\mathrm{C}$

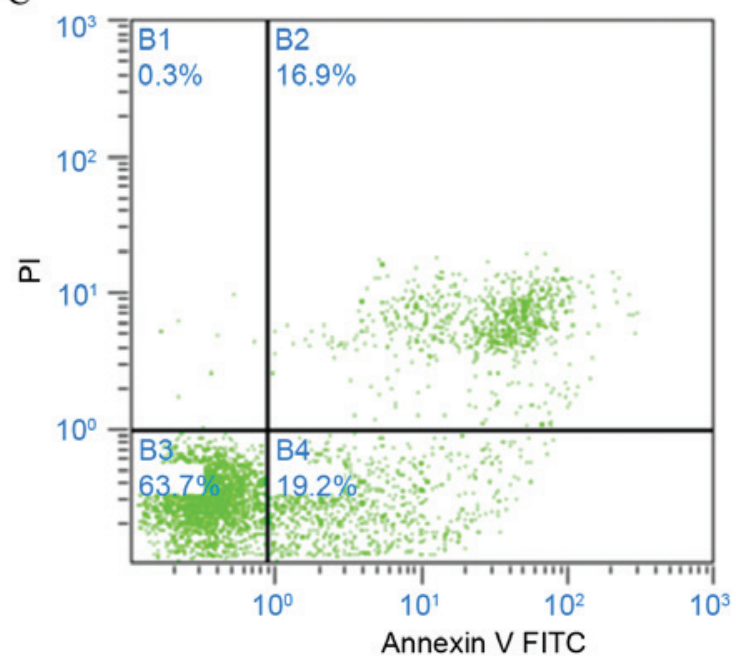

B

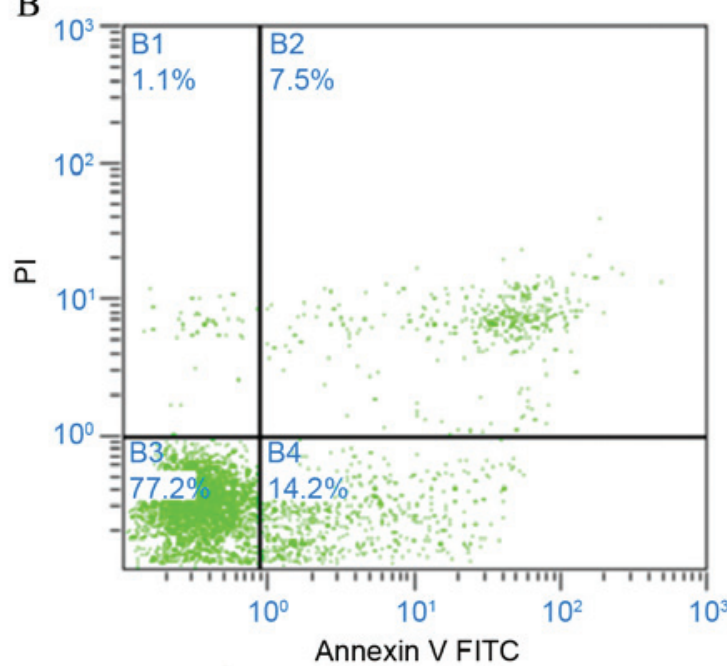

D

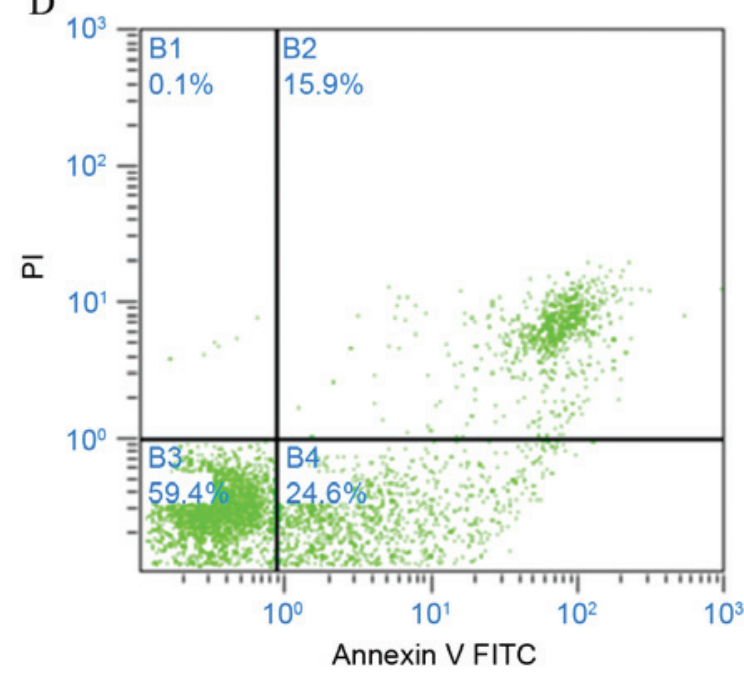

Figure 7. Detection of cell apoptosis by Annexin V-FITC/PI staining of a single experiment. (A) 0; (B) 5; (C) 10; and (D) 20 mg/ml flavonoid treatment groups.

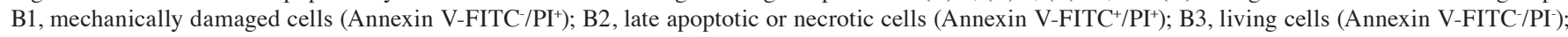
and B4, with early apoptotic cells (Annexin $\mathrm{V}-\mathrm{FITC}^{+} / \mathrm{PI}^{-}$). FITC, fluorescein isothiocyanate; PI, propidium iodide.

compared with group B $(\mathrm{P}<0.01)$. Furthermore, the rate of inhibition markedly increased with time at each concentration (Table IV). These results indicated that flavonoids promoted the apoptosis of MKN45 cells in a dose- and time-dependent manner.
Pro-apoptotic effects of flavonoids on MKN45 cells. As observed from dual-parameter dot plots, MKN45 cells of the blank control group were primarily distributed in the B3 zone, indicating that few cells had undergone apoptosis when compared with the other treatment groups (Fig. 7). Analysis 
Table V. Pro-apoptotic effect of flavonoids on MKN45 cells.

\begin{tabular}{lc}
\hline Group & Apoptotic rate $(\%)$ \\
\hline A & $11.73 \pm 0.60$ \\
B & $13.70 \pm 0.46^{\mathrm{a}}$ \\
C & $19.43 \pm 0.49^{\mathrm{b}, \mathrm{c}}$ \\
D & $24.23 \pm 0.40^{\mathrm{b}, \mathrm{c}}$
\end{tabular}

Apoptotic rate is based upon the percentage of cells stained as Annexin V-FITC ${ }^{+} / \mathrm{PI}^{+}$(necrotic). Data are presented as the mean \pm standard deviation, $n=3$. ${ }^{\mathrm{a}} \mathrm{P}<0.05$ and ${ }^{\mathrm{b}} \mathrm{P}<0.01$ vs. group $\mathrm{A}$; ${ }^{\mathrm{C}} \mathrm{P}<0.01$ vs. group B. A, blank control; $\mathrm{B}$, low-dose; $\mathrm{C}$, moderate-dose; $\mathrm{D}$, high-dose.

of the flow cytometry data indicated that pretreatment with flavonoids induced the apoptosis of MKN45 cells, as demonstrated by a significantly increased rate of apoptosis in groups $\mathrm{B}(\mathrm{P}<0.05), \mathrm{C}$ and $\mathrm{D}$ (both $\mathrm{P}<0.01)$ when compared with the control group. Furthermore, the rate of apoptosis increased as flavonoid concentration increased, with a significantly greater apoptotic rate observed in groups $\mathrm{C}$ and $\mathrm{D}$ when compared with group $\mathrm{B}(\mathrm{P}<0.01$; Table $\mathrm{V})$.

\section{Discussion}

Chrysanthemum morifolium is mainly produced in Tongxiang city in Zhejiang province, and is among the first genuine and edible medicinal materials to be approved by the Ministry of Health (Beijing, China) (25). As one of 'the eight genuine traditional Chinese Medicines of Zhejiang' (26), Chrysanthemum morifolium may be eaten as food and used as a medicine. Chrysanthemum morifolium was recently included in the Chinese Pharmacopoeia (2010 version) (2), and contains flavonoids and triterpenoids as the main active ingredients (27).

Ultrasonic extraction is a novel method used to enhance production yield and to avoid thermal damage (28). It has been used in previous studies to extract natural products (29) and improve solvent extraction, mainly due to the mechanical effects of cavitational bubble collapse, causing better solvent penetration into plant materials $(30,31)$. In the single factor experiment of the present study, the yield of flavonoids reached the maximum $4.87 \%$ by using ultrasonication for $40 \mathrm{~min}$. Compared with the traditional extraction method, ultrasonication was simple and time-saving. The result is consistent with previous studies $(32,33)$. Therefore, ultrasonication exhibits strong potential as a method for enhancing production yield during extraction from traditional Chinese medicine. The present findings indicated the effect of ultrasonic extraction on the yield of flavonoids from Chrysanthemum morifolium. However, to obtain more active ingredients from Chrysanthemum morifolium, further studies such as the addition of ultrasonic frequency are required.

Mathematical modeling is an effective statistical model for investigating the influences of different factors on extraction, as well as indicating the optimal conditions of extraction (34). Among the current modeling methodologies, orthogonal experimental design is an efficient way for addressing multifactorial experiments and screening optimum levels by using the orthogonal design table and statistical analysis (14). Factors that typically influence the extraction of flavonoids from Chrysanthemum morifolium include the duration of ultrasonic treatment, ethanol concentration, temperature and liquid-to-solid ratio $(32,35)$. Using a single factor experiment and orthogonal test design, the extraction process was optimized in the present study, and the following was determined as the optimal combination of factors: Duration of ultrasonic treatment, $35 \mathrm{~min}$; ethanol concentration, $75 \%$; temperature, $80^{\circ} \mathrm{C}$; and liquid-to-solid ratio, 25:1. Under the above conditions, the yield of flavonoids reached a maximum of $5.24 \%$. The duration of ultrasonic treatment exerted the greatest impact on flavonoid yield, followed by temperature, liquid-to-solid ratio and ethanol concentration. Orthogonal experimental design was also used to optimize extraction process in previous reports $(32,36,37)$. Thus, these findings suggest that the optimum conditions for extracting flavonoids may be determined by using orthogonal test design.

The pharmacological activities of Chrysanthemum morifolium include reductive effects on blood lipid, blood sugar (38) and blood pressure, and anti-oxidative (39), antitumor (40), neuroprotective (41), hepatoprotective (42) and cardioprotective effects (43). Through an in vitro antitumor activity test, the present study observed that flavonoids extracted from Chrysanthemum morifolium inhibited the proliferation of MKN45 cells in a dose- and time-dependent manner. Similarly, it had been reported that the flavonoids from Chrysanthemum morifolium indicated significant cytotoxicities against human breast cancer cells, liver cancer cells (44) and colon cancer cells (22) by using the MTT assay. Furthermore, Annexin V-FITC/PI staining and flow cytometry were used to discriminate apoptotic and necrotic cells, and results indicated that flavonoids may induce tumor cell apoptosis in a dose-dependent manner. To conclude, Chrysanthemum morifolium can be exploited for its medicinal properties against cancer.

\section{Acknowledgements}

The present study was supported by the National Natural Science Foundation of China (grant no. 81273623), the Health and Family Planning Commission of Zhejiang Province (grant no. 2017KY129) and the Traditional Chinese Medicine Science and Technology Foundation of Zhejiang Province (grant no. 2016ZA155).

\section{References}

1. Editor Committee of Jiangsu New Medical College Encyclopedia of Traditional Chinese Medicine. Shanghai Science and Technology Press, Shanghai, pp2008-2011, 1995.

2. Chinese Pharmacopoeia Commission, 2010: Pharmacopoeia of the people's Republic of China Version 2010. Chinese Medicine Science Technology Press, Beijing, pp292, 2010.

3. Sun QL, Hua S, Ye JH, Zheng XQ and Liang YR: Flavonoids and volatiles in Chrysanthemum morifolium Ramat flower from Tongxiang County in China. Afr J Biotechnol 9: 3817-3821, 2010.

4. Sugawara T and Igarashi K: Identification of major flavonoids inpetals of edible Chrysanthemum flowers and their suppressive effect on carbon tetrachloride-induced liver injury in mice. Food Sci Technol Res 15: 499-506, 2009. 
5. Wang L, Wang T, Guo QS, Huang Y and Xu HK: Comparative study on four major active compounds of Sanvitalia procumbens and Chrysanthemum morifolium cv 'Hangju' and 'Gongju'. Zhongguo Zhong Yao Za Zhi 38: 3442-3445, 2013 (In Chinese).

6. Zheng C, Dong Q, Chen H, Cong Q and Ding K: Structural characterization of a polysaccharide from Chrysanthemum morifolium flowers and its antioxidant activity. Carbohydr Polym 130: 113-121, 2015.

7. Lin LZ and Harnly JM: Identification of the phenolic components of chrysanthemum flower (Chrysanthemum morifolium Ramat). Food Chem 120: 319-326, 2010.

8. Niu YF, Han CM, Shao Y and Tao YD: Comparative study on eight trace elements in twelve flower medicines. Guang Pu Xue Yu Guang Pu Fen Xi 29: 1997-2000, 2009 (In Chinese).

9. Jin JZ, Wen M and Shen TC: Research progress in chemical components in Chrysanthemum Morifolium. Sci Technol Food Industry 35: 386-394, 2014.

10. Xia DZ, Lv GY, Yu XF, Wang HM and Yang Q: Antagonism of total flavonoids from Chrysanthemum morifolium against lead induced oxidative injury in mice. Zhongguo Zhong Yao Za Zhi 33: 2803-2808, 2008 (In Chinese).

11. Liu YH, Zhou DY, Shou CM and Mou X: Effect of flavonoids from Chrysanthemum morifolium on Bax and Bcl-2 mRNA expressions induced by high glucose in vascular endothelial cells. China J Trad Chinese Med Pharm 30: 2504-2507, 2015 (In Chinese).

12. Tu PF, Shi SP and Jiang Y: Material basis for efficacy of traditional Chinese medicine research ideas and methods overview. Chinese Herb Med 43: 209-215, 2012 (In Chinese).

13. Wang SJ, Wu ZF, Yang M, Wang YQ, Wang F, Ke G and Huang JM: Research status and translational application of new extraction techniques of traditional Chinese medicine. Zhongguo Zhong Yao Za Zhi 39: 1360-1367, 2014 (In Chinese).

14. Ji LJ, Si YF, Liu HF, Song XL, Zhu W and Zhu AP: Application of orthogonal experimental design in synthesis of mesoporous bioactive glass. Micropor Mesopor Mat 184: 122-126, 2014.

15. Gao X, Li Q, Cheng W, Han G and Xuan L: Optimization of high temperature and pressurized steam modified wood fibers for high-density polyethylene matrix composites using the orthogonal design method. Materials (Basel) 9: E847, 2016.

16. Wang HJ, Pan MC, Chang CK, Chang SW and Hsieh CW: Optimization of ultrasonic-assisted extraction of cordycepin from Cordyceps militaris using orthogonal experimental design. Molecules 19: 20808-20820, 2014.

17. Torre LA, Bray F, Siegel RL, Ferlay J, Lortet-Tieulent J and Jemal A: Global cancer statistics, 2012. CA Cancer J Clin 65: 87-108, 2015

18. Pongjit $\mathrm{K}$, Ninsontia $\mathrm{C}$, Chaotham $\mathrm{C}$ and Chanvorachote $\mathrm{P}$ : Protective effect of Glycine max and Chrysanthemum indicum extracts against cisplatin-induced renal epithelial cell death. Hum Exp Toxicol 30: 1931-1944, 2011.

19. Wu XN, Yu CH and Bao QN: Anti-inflammatory effect and mechanism study of total flavonoids in Chrysanthemum morifolium Ramat. Chinese J Clin Pharmacol Ther 14: 1000-1004, 2009 (In Chinese).

20. Cheng W, Li J, You T and Hu C: Anti-inflammatory and immunomodulatory activities of the extracts from the inflorescence of Chrysanthemum indicum Linné. J Ethnopharmacol 101: 334-337, 2005.

21. Yu HN, Sun C, Shan WG and Shen SR: Semi-bionic extraction of active components against stomach cancer from chrysanthemum J Zhejiang Univ Technol 40: 630-633, 2012 (In Chinese).

22. Xie YY, Yuan D, Yang JY, Wang LH and Wu CF: Cytotoxic activity of flavonoids from the flowers of Chrysanthemum morifolium on human colon cancer Colon205 cells. J Asian Nat Prod Res 11: 771-778, 2009.

23. Wang H, Zhang X, Li Y, Chen R, Ouyang S, Sun P, Pan L, Ren H and Yang B: Antitumor activity of a polysaccharide from longan seed on lung cancer cell line A549 in vitro and in vivo. Tumour Biol 35: 7259-7266, 2014.

24. Alenzi FQ: Links between apoptosis, proliferation and the cell cycle. Br J Biomed Sci 61: 99-102, 2004.

25. Wu XJ, Yu CH and Bao QN: Anti-inflammatory effect and mechanism study of total flavonoids in Chrysanthemum morifolium Ramat. Chinese J Clin Pharmacol Ther 14: 1000-1003, 2009 (In Chinese).
26. Yu SK, Zhang Y and Wu XQ: Nutritional components and biological activities of Chrysanthemum morifolium. Food Nutri China 2: 51-52, 2002 (In Chinese).

27. Wang S, Hao LJ, Zhu JJ, Zhang QW, Wang ZM, Zhang X and Song XM: Study on the effects of sulfur fumigation on chemical constituents and antioxidant activity of Chrysanthemum morifolium cv. Hang-ju. Phytomedicine 21: 773-779, 2014.

28. Liao JQ, Qu BD, Liu D and Zheng NQ: New method to enhance the extraction yield of rutin from Sophora japonica using a novel ultrasonic extraction system by determining optimum ultrasonic frequency. Ultrason Sonochem 27: 110-116, 2015.

29. Li X, Wang Z, Wang L, Walid E and Zhang H: Ultrasonic-assisted extraction of polysaccharides from Hohenbuehelia serotina by Response surface methodology. Int J Biol Macromol 51: 523-530, 2012.

30. Paniwnyk L, Cai H, Albu S, Mason TJ and Cole R: The enhancement and scale up of the extraction of anti-oxidants from Rosmarinus officinalis using ultrasound. Ultrason Sonochem 16: 287-292, 2009.

31. Hsieh CW, Cheng JY, Wang TH, Wang HJ and Ho WJ: Hypoglycaemic effects of Ajuga extract in vitro and in vivo. J Funct Food 6: 224-230, 2014

32. Yin $\mathrm{H}, \mathrm{Hu} \mathrm{YZ}$, Yang XJ, Sheng $\mathrm{J}$ and Wang Z: Study on ultrasonic extraction technics of flavonoids in Chrysanthemum morifolium. Zhongguo Zhong Yao Za Zhi 29: 424-425, 2004 (In Chinese)

33. Zhang GH, Qiao JW and Zhang RS: Optimization of ultrasonic extraction of flavonoids from Chrysanthemum morifolium by response surface methodology. Asia-Pacific Trad Med 5: 20-22, 2009.

34. Tao Y, Wu D, Zhang QA and Sun DW: Ultrasound-assisted extraction of phenolics from wine lees: Modeling, optimization and stability of extracts during storage. Ultrason Sonochem 21: 706-715, 2014.

35. Yang J, Jiang HD and Xu JH: Study on extraction technics and variety trends of flavonoids in Chrysanthemum morifolium. Zhong Cao Yao 33: 988-990, 2002 (In Chinese).

36. Yin H, Hu YZ, Yang XJ, Tian YL and Wang Z: Study on extraction technology for extract and flavonoids in Chrysanthemum morifolium by orthogonal design. Zhongguo Zhong Yao Za Zhi 29: 737-739, 2004 (In Chinese).

37. Xu XQ, Chen HH and Li XM: Optimization of ultrasound-assisted extraction of total flavonoids from Chrysanthemum indicum L. Asia-Pacific Trad Med 7: 21-22, 2011

38. Yamamoto J, Tadaishi M, Yamane T, Oishi Y, Shimizu M and Kobayashi-Hattori K: Hot water extracts of edible Chrysanthemum morifolium Ramat. exert antidiabetic effects in obese diabetic KK-Ay mice. Biosci Biotechnol Biochem 79: 1147-1154, 2015.

39. Kuang CL, Lv D, Huang X, Gao W, Shen GH and Zhang ZQ: A study on the anti-oxidative activity of Chrysanthemum morifolium extract using different solvents. Sci Technol Food Industry 36: 83-87, 2015.

40. Hu WX, Mao WF, He C, Zhang L, Huang XF, Du WD and Fang BL: Chrysanthemum morifolium Ramat sensitizes TNF-related apoptosis inducing ligand-induced apoptosis in human colon cancer cell line DLD-1. Chin J Pathophysiol 22: 742-747, 2006.

41. Kim IS, Koppula S, Park PJ, Kim EH, Kim CG, Choi WS, Lee KH and Choi DK: Chrysanthemum morifolium Ramat (CM) extract protects human neuroblastoma SH-SY5Y cells against MPP+-induced cytotoxicity. J Ethnopharmacol 126: 447-454, 2009.

42. Kang WY, Huang H, Lian TT and Xu QT: A study on hepatoprotective effect of Chrysanthemum morifolium. Natural Product Res Develop 24: 1634-1636, 2012.

43. Liu YH, Zhou DY, Shou CM and Mou X: The influence of flavonoids from Chrysanthemum morifolium on the apoptosis of HUVEC. Zhejiang J Integrated Traditional Chinese Western Med 24: 571-572, 2014.

44. Peng YF, Zou WT and Xu CL: Evaluation of flavonoids from flos chrysanthem ion cell proliferation in human cancer cells. Chin Pharm J 45: 1454-1459, 2010 (In Chinese).

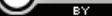

This work is licensed under a Creative Commons Attribution 4.0 International (CC BY 4.0) License. 